\title{
Assessment of the Application of Micro-Irrigation Systems and Calculation of the Definition of its Economic Efficiency in the Conditions of Azerbaijan
}

\author{
Rae ZH Aliye* \\ Institute of Soil Science and Agro chemistry of NAS of Azerbaijan, Azerbaijan
}

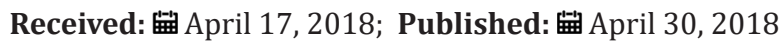

*Corresponding author: Rae ZH Aliye, Institute of Soil Science and Agro chemistry of NAS of Azerbaijan, Azerbaijan

\begin{abstract}
Annotation
For a well-known purpose in 2010-2015, Guba-Khachmaz RAEM, Tartar and RAEM Shamakhi TSB have been confirmed by numerous research findings in the field of mountain watering, in terms of the development of irrigation, the mountainous slopes include soybean, sugar beet, trees, and germination (barley, wheat, etc.), the microcirculation method was not cost-effective in terms of efficiency, and preventive measures such as surface soil wash, sliding, irrigation and drowning, erosion characteristic for mountainous terrain zones, which is of particular importance, confirms the feasibility study of the farm calculated with the following formula.
\end{abstract}

Keywords: Leakage; Micro-irrigation; Investment; Bringing costs; Irrigation

\section{Introduction}

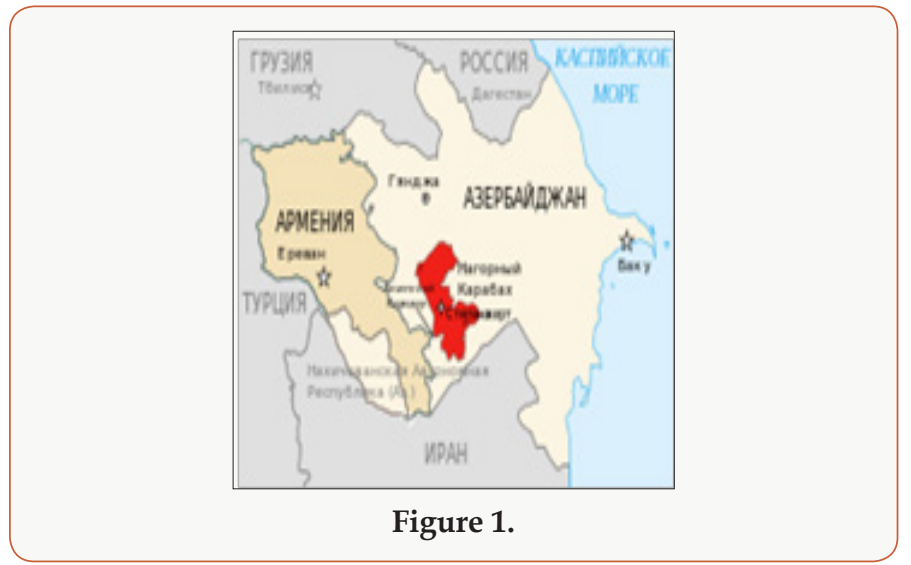

(Figure 1) Rapid growth of the world population, limited land plots, lack of fresh water resources, environmental degradation, climate variability and so on. problems have highlighted the problem of food humanity, which in turn requires proper regulation of land protection and improvement of the public administration mechanism of land resources. From this point of view, $60 \%$ of the land with difficult relief and complex natural climatic characteristics has been eradicated from the threatened state of the intensive development of mountainous zones and has been partially implemented in order to rehabilitate the fertility of these areas in the direction of agricultural destination, The scientific and economic importance of irrigation irrigation systems for progressive water is an undeniable fact. In this regard, it is aimed to calculate the effectiveness of these irrigation systems with more accurate method and methodology. The calculation of the economic efficiency of the use of the microscopy in terms of production experience with respect to the application of the application of the microscopy is considered to be one of the key factors.

\section{The Course of the Study}

In accordance with the methodology for determining the importance of the application of new techniques and technology applied to the existing agricultural sector, the annual economic benefit obtained by the application of sugar beet micro-gradient is as follows:

$$
E=\left(T S_{2}-w_{2}\right)-\left(T S_{1}-w_{1}\right) / a-{ }_{2}
$$

here $w_{1}$ and $w_{2}$ [1] hectares base case and new sources for the introduction of products owned by agricultural practices directly with the account mentioned costs; with USD. TS TS and -1 hectares base case and new sources of agricultural techniques involved, giving accounts belonging to the production plant; from 
USD. And [2] -annual volume applicator, ha. He compared to the sources of new methods for sufferers of traditionally implemented furrows watering sources. Ammortizasiya countries, major industrial distribution ammortizasiya popular norma and fond of Shamil running costs and repair costs in "Sojuzvodproekt"-n recommendations methodological guidance mainly accredited [3]. And studied at the settlement, belonging to the current irrigation natural indicators (parameters) Importance of the importance of Daka important elements in analysis. Micro-irrigation's a series of hail shower processes physiological Mammary sugar, basic version compared to $20 \%$ to stimulation, he believes qn (cf. 1). From the table, July-October, months hang sources. This product is comparable to a $32.4 \%$ microscope option and down to the country's product range of $54.3 \mathrm{~s} / \mathrm{ha}$. In this difference, serious sources of water are effective (Table 1). This is the largest amount of supplies in the United States dollars volumesopposite Table 1: Effect of yield of sugar beets from Micro-irrigation. or complementary sources of water is to take prices production Shehzad (increment) is generally characterized by (Table 2 ). Table 2 also available with situations mentioned, mikrosuvarmada/1 cents to get additional product name şırım Deng with sh 2-2, 5 times less water to spend relatively olunurki and that the sources of saving water [4]. Economic comparative efficiency sources for questioning, is the microelements macro and cotton from sugar beet using micro-irrigation with an additional set of products that have been achieved before Wahid overloaded costs the cost of establishing the system of mikrosuvarma, according to the variant set of products in production costs (labor, land cultivation) taken into consideration and s. (Tables $3 \& 4$ ). the report results Table 5-inch Micro-irrigation is generally characterized by observable short produced sugar beet, Ana Rajendra indicators during PA effectiveness will depend on several noted:

\begin{tabular}{|c|c|c|c|c|c|}
\hline $\begin{array}{c}\text { Research, convening } \\
\text { duration }\end{array}$ & Options & Sources from among & $\begin{array}{c}\text { Sources normasi } \\
\text { (m)3/h.(A) }\end{array}$ & $\begin{array}{c}\text { Average performance } \\
\text { simply s/ha }\end{array}$ & $\begin{array}{c}\text { water at the units } \\
\text { product; m3/ha }\end{array}$ \\
\hline July October & Micro-irrigation & 16 & 4490 & 318.2 & 14.1 \\
\hline July October & Borozdovye glaze & 5 & 5294 & 263.9 & 20.06 \\
\hline July October & Control\%-ith & & 84.81 & 180.6 & 70.3 \\
\hline
\end{tabular}

Table 2: Sources of water in the production of effective use of for sugar beets (July-October months average).

\begin{tabular}{|c|c|c|c|}
\hline Options & $\begin{array}{c}\text { Sources of standards; (actual } \\
\text { cost) } \mathbf{~ m}^{3} / \mathbf{h} \text { and }\end{array}$ & $\begin{array}{c}\text { Average performance simply cents } \\
\text { from the internal TS/(h).(A) }\end{array}$ & $\begin{array}{c}\text { Units of additional sources of water harvest } \\
\text { production mentioned costs (costs of water) } \mathbf{m}^{3} / \\
\text { cents from the internal }\end{array}$ \\
\hline $\begin{array}{c}\text { furrow } \\
\text { irrigation }\end{array}$ & 5294 & 263.9 & 59.7 \\
\hline Micro-irrigation & 4490 & 318.2 & 31.4 \\
\hline
\end{tabular}

Table 3: According to agricultural cultivation and maps of harvest sugar beets.

\begin{tabular}{|c|c|c|c|c|}
\hline Info names & The unit of measurement & room & Free (USD) & Only (USD) \\
\hline 1. resources :-Seeds & KQ & 4 & 26.06 & 104.24 \\
\hline -Annual cost of water sources & (h). AND/DOL & 1 & 4.8 & 4.8 \\
\hline $\begin{array}{l}\text { 2.labour and torpaqişləri :-the surface area of Earth (layout) } \\
\text { hamatrlanması }\end{array}$ & (h). (A) & 1 & 77.6 & 77.6 \\
\hline -Sham said APA of & (h).(A) & 1 & 12.77 & 12.77 \\
\hline -HARROWING & times & 2 & 4.26 & 8.52 \\
\hline -Sowing Seeds & (h).(A) & 1 & 6.38 & 6.38 \\
\hline -furrow of Opening & (h). (A) & 1 & 6.38 & 6.38 \\
\hline cultivation measures & times & 4 & 6.38 & 25.52 \\
\hline -tillage & TIMES & 3 & 32 & 96 \\
\hline 3. harvest my stack: -harvest & TONE & 26.39 & 1.06 & 27.97 \\
\hline -edilmə transport (car karvanı & TONE & 26.39 & 1.6 & 42.22 \\
\hline Total: & & & & 412.4 \\
\hline
\end{tabular}


Table 4: According to agricultural cultivation costs spent cards and harvesting of sugar beet.

\begin{tabular}{|c|c|c|c|c|}
\hline Info names & $\begin{array}{l}\text { This measure was all } \\
\text { played }\end{array}$ & Issue (amount) & Free USD. With & $\begin{array}{l}\text { For only USD. } \\
\text { With }\end{array}$ \\
\hline 1. resources :-Seeds & KG & 4 & 26.06 & 104.24 \\
\hline $\begin{array}{l}\text {-annual consumption of property, water sources } \\
\text { can be downloaded }\end{array}$ & (h). AND /DOL & 1 & 4.8 & 4.8 \\
\hline -Gübrələrtin can be downloaded:- nitrogen (N) & KQ & 150 & 0.12 & 18 \\
\hline - Phosphor (P) & $\mathrm{KQ}$ & 120 & 0.16 & 19.2 \\
\hline - potassium (K) & KQ & 90 & 0.16 & 14.4 \\
\hline - BOR (B) & $\mathrm{KQ}$ & 4 & 0.43 & 1.72 \\
\hline - molybdenum (Mo) & $\mathrm{KQ}$ & 3 & 0.43 & 1.29 \\
\hline $\begin{array}{l}\text { 2. Mikrosuvarma cost of building systems :This, } \\
\text { including }\end{array}$ & & & & 8655 \\
\hline -Micro System sources (komplekt) & k-t & 1 & & 4615 \\
\hline -bulk water pipe-line network & p. m & 3200 & & 2268 \\
\hline -Hydrants & $\mathrm{PC}$ & 1 & & 107 \\
\hline -Fertigation approach in & PC & 3 & & 679 \\
\hline -micro water outlet apparatus & $\mathrm{PC}$ & 260 & & 136 \\
\hline -Nasos Kits & $\mathrm{PC}$ & 1 & & 850 \\
\hline 3. labour market : -Y aparmaq & (h). (A) & 1 & 12.77 & 12.77 \\
\hline -HARROWING & times & 2 & 4.26 & 8.52 \\
\hline -Seeds (seeding) & (h). (A) & 1 & 6.38 & 6.38 \\
\hline -reclamation & times & 4 & 6.38 & 25.52 \\
\hline Earth çevirmə (effort) & times & 3 & 32 & 96 \\
\hline 4. harvest my stack : -harvest & tons & 69.43 & 1.06 & 73.59 \\
\hline -Transport (Kura River originates from Water) & tons & 69.43 & 1.6 & 111.01 \\
\hline Total: & & & & 9152.44 \\
\hline
\end{tabular}

Table 5: Economic evaluation of sugar beet micro-irrigation.

\begin{tabular}{|c|c|c|c|c|}
\hline Indicators & $\begin{array}{l}\text { The unit of } \\
\text { measurement }\end{array}$ & Motto and & $\begin{array}{l}\text { Furrow without } \\
\text { fertilizer sources }\end{array}$ & $\begin{array}{l}\text { With the use of micro- } \\
\text { irrigation C.150P120K90+ } \\
\text { B4Mon3 }\end{array}$ \\
\hline (I). Area Sources (application) & (h). (A) & And2 & 1 & 1 \\
\hline $\begin{array}{l}1 \mathrm{~h} . \text { And the area is the production of Ana şəkər } \\
\text { (value with application) }\end{array}$ & USD/h (A) & TS1; TS2 & 514.4 & 4199.4 \\
\hline Irrigation the increment of additional product & USD/ (h). (A) & (D) Ts1; (D) TS2 & 273.3 & 1597 \\
\hline $\begin{array}{l}\text { (II). Zemlo- construction works (cost) of the special } \\
\text { measures, including: }\end{array}$ & USD/ (h). (A) & To1; To2 & 84 & 8655 \\
\hline -micro-irrigation komplekt & USD/ (h). (A) & PC & & 4615 \\
\hline -Trunk pipe linear Seth & USD/ (h). (A) & PC & & 2268 \\
\hline -Hydrants & USD/ (h). (A) & PC & & 107 \\
\hline -hydrogenating devices & USD/h $(A)$ & PC & & 679 \\
\hline -mikroorositelnye machines & USD/ (h). (A) & PC & & 136 \\
\hline -Pump Kits & USD/ (h). (A) & $\mathrm{PC}$ & & 850 \\
\hline III. Expenses çəkiləcək Suvarmaya & USD/ (h). (A) & With1; (C)2 & 4.8 & 350 \\
\hline Directly to the costs & USD/ (h). (A) & W1; W2 & 412.4 & 9152.44 \\
\hline given the cost & USD/ (h). (A) & Pr1; Pr2 & 425 & 1800 \\
\hline $\begin{array}{l}\text { (IV). Sources of water in cotton cultivation (1000 m3 } \\
\text { with an account ) }\end{array}$ & USD/M3 & & 51.6 & 355.7 \\
\hline
\end{tabular}




\begin{tabular}{|c|c|c|c|c|}
\hline (V) Labour unit costs. for irrigation & man.day/h. (A) & OST(F) & & 1 \\
\hline (VI) . Annual economic səmərə $1 \mathrm{~h}$. And -from & USD / h. (A) & $\mathrm{E}$ & & 2310 \\
\hline $\begin{array}{l}\text { Water Get the owner before income: }-1(\mathrm{~h}) \text {. And } \\
\text {-from }\end{array}$ & USD $/ \mathrm{h} .(\mathrm{A})$ & $\begin{array}{l}\mathrm{P}=\mathrm{D}-\mathrm{c} \text { (with c } \\
\quad+\text { Extras) }\end{array}$ & 198.3 & 3012.4 \\
\hline$-1000 \mathrm{~m} 3$ of water account & USD/M3 & & 37.5 & 670.9 \\
\hline Skirting option compared to the extra income & USD & (D) p (n2-1) and2 & & 2813.7 \\
\hline Duration Investicion nyhvlozhenij & Provincial & $\begin{array}{l}\text { I.e.Ok=To2-To-1 } \\
\text { N2-1 }\end{array}$ & & 3 \\
\hline
\end{tabular}

a) New Micro-irrigation technology application gives you the opportunity to increase the sources of water this means $90 \%$, so the sources of water for more than 2 times in savings;

b) Labour cost fee-owned SH 3 has dropped from more than times;

c) Traditional furrow irrigation sugar beets is compared with an embedded micro-irrigation systems from annual economic income of \$959.6, for reality in 3's provinces from additional 1 hectare reclaimed area average investment return in the year.

Ecology of economically reliable, efficient and economic point reasonable are one of the sources who develop it worshipped the mikrosuvarma experience scientific institutions in our country system, produced the social sphere, pole təsərrüfanlarında and other qurumlarında to be self-sufficient it is spread wide, this mountain was regarded [5] agriculture as sources to use to obtain ownership of agricultural bitkilərindən Ecology of the retrieval of a set of products enables you to clean it. Now 25 metres below according to main, Nagorno positions in the zone zonada duties YAP torpaqlarında area management and mikrosuvarmanın economic efficiency identification and here is the production they created new gardens and Vineyard development of Fame main götürülərək system applied to them economic to be evaluated. That's on top of research appointed economic efficiency will depend on several, 6) Table 6: According to Agrotechnical maps on the fruits of the tree of the costs.

\begin{tabular}{|c|c|c|c|c|}
\hline Info names & $\begin{array}{l}\text { The unit of } \\
\text { measurement }\end{array}$ & Issue (amount) & Free (USD) & Only (USD) \\
\hline 1 & 2 & 3 & 4 & 5 \\
\hline (I). Investment Including: & & & & 1782 \\
\hline $\begin{array}{l}\text { 1. the costs of installing the system Mikrosuvarma } \\
\text { including: }\end{array}$ & & & & 1006 \\
\hline -metal pipes & \multirow{2}{*}{$(\mathrm{m})$} & \multirow{2}{*}{2.4} & \multirow{2}{*}{4.08} & \multirow{2}{*}{9.79} \\
\hline$Æ 76 \times 3.0$ & & & & \\
\hline$Æ 50 \times 2.2$ & $(\mathrm{p}) \cdot(\mathrm{m})$ & 14.4 & 3.41 & 49.1 \\
\hline -Plastics pipe & \multirow{2}{*}{$(p) \cdot(m)$} & \multirow{2}{*}{91} & \multirow{2}{*}{0.73} & \multirow{2}{*}{66.28} \\
\hline Æ $75 \times 8.1$ & & & & \\
\hline$Æ 50 \times 5.4$ & $(\mathrm{p}) \cdot(\mathrm{m})$ & 574 & 0.58 & 332.92 \\
\hline$Æ 20 \times 2.2$ & (p) $\cdot(m)$. & 250 & 0.13 & 35.5 \\
\hline \multicolumn{5}{|l|}{-elements of metal contract } \\
\hline Three çucaqlılar: & PC & & & \\
\hline
\end{tabular}




\begin{tabular}{|c|c|c|c|c|}
\hline$Æ=75 \times 75 \times 75$ & & 2 & 6.1 & 12.2 \\
\hline REINFORCING=75×50x75 & & 3 & 5.45 & 16.35 \\
\hline bucaqlilar: & $\mathrm{PC}$ & & & \\
\hline$Æ 75 \times 75$ & & 2 & 4.9 & 9.8 \\
\hline Æ $50 \times 50$ & & 8 & 4.01 & 32.08 \\
\hline -Plastic contract elements & \multirow{2}{*}{ PC } & \multirow{2}{*}{3} & \multirow{2}{*}{0.61} & \multirow{2}{*}{1.83} \\
\hline Three çucaqlılar: & & & & \\
\hline \multicolumn{5}{|l|}{ REINFORCING $=50 \times 50 \times 50$} \\
\hline REINFORCING=50x20x50 & & 4 & 0.51 & 2.04 \\
\hline Bucaqlilar: reinforcing steel $50 \times 50$ & $\mathrm{PC}$ & 2 & 0.5 & 1 \\
\hline clutch : Reinforcing 75 & PC & 4 & 0.81 & 3.24 \\
\hline REINFORCING 50 & & 5 & 0.6 & 3 \\
\hline Keçidlər Reinforcing= $75 \times 63$ & & 1 & 0.92 & 0.92 \\
\hline REINFORCING $=63 \times 50$ & & 1 & 0.82 & 0.82 \\
\hline -Valves: & $\mathrm{PC}$ & 3 & 7.55 & 22.65 \\
\hline \multicolumn{5}{|l|}{$\mathrm{Du}=50(156 / \mathrm{BR})$} \\
\hline - Nasos RZK-6 & PC & 1 & 400 & 400 \\
\hline -Suburaxicılar & $\mathrm{PC}$ & 18 & 0.36 & 6.48 \\
\hline $\begin{array}{c}\text { 2.V=25 m3volume of water amount of metal çənin } \\
\text { hairlanması and installation }\end{array}$ & & & & 250 \\
\hline -metallic materials & $\mathrm{PC}$ & 285 & 700 & 200 \\
\hline -To install & & & & 50 \\
\hline 3.mənbəyiyindəki gerayli water and karataj works & & & & 226 \\
\hline 4.0.25 ha size Terrace land construction apar işlərinin & (p) Meters. & 250 & 1.2 & 300 \\
\hline $\begin{array}{l}\text { During the second world war. Aqrotexniki fruit tree } \\
\text { proqrama for processing recurring charges : Including: }\end{array}$ & & & & 80.13 \\
\hline 1. tinklər & $\mathrm{PC}$ & 154 & 0.5 & 77 \\
\hline 2.36 PCs for wood gübrə (physical reselling program) & KQ & 210 & 0.12 & 31.38 \\
\hline -Nitrogen $(\mathrm{N})$ & KQ & 65.4 & 0.12 & 7.8 \\
\hline -Phosphor (R) & KQ & 117.34 & 0.16 & 18.7 \\
\hline -Potassium (K) & KQ & 25.12 & 0.16 & 4 \\
\hline -Bor (In) & KQ & 1.2 & 0.43 & 0.5 \\
\hline -Sink (Zn) & KQ & 0.89 & 0.43 & 0.38 \\
\hline 3. chemical preporat: & \multirow{2}{*}{ KQ } & \multirow{2}{*}{3.1} & \multirow{2}{*}{1.5} & \multirow{2}{*}{4.65} \\
\hline -DNOC & & & & \\
\hline 4. Suvarmaların from: & \multirow{2}{*}{$(\mathrm{m}) 3$} & \multirow{2}{*}{66.2} & \multirow{2}{*}{0.0041} & \multirow{2}{*}{0.27} \\
\hline -drip sources & & & & \\
\hline -Springs with Groove & M3 & 159 & 0.0041 & 0.7 \\
\hline 5. give a mineral fertilizer & times & 3 & 2.45 & 7.35 \\
\hline 6. chemical preporat give & times & 1 & 3.38 & 3.38 \\
\hline 7. Tink surroundings earned on the ground boşaldılması & $\mathrm{PC}$ & 54 & 0.1 & 5.4 \\
\hline $\begin{array}{l}\text { 8. Mastering the micro-irrigation systems for farmers } \\
\text { education seminar portal created in Azerbaijan }\end{array}$ & times & 4 & 160 & 640 \\
\hline Total: & & & & 2532.13 \\
\hline
\end{tabular}

\section{Note}

a) Low-intensity (micro drip irrigation sources hot and s.) the establishment of a system of recurrent expenditure sources really $\$ 606$ is because locking-pumps 400 USD, establish stocks of some unwinding of the following. This natural water in the summer, it is considered that the lack of ownership of water scarcity in the country, its water will be used from another source (small reservoirs) necessary. 
b) ASMO is an integral part of the technology systems for automated control system is not given for free, so, in a small area and also in the objects of study due to its great expense and it is not installed in the system account is not maintained Therefore, the record.

\section{References}

1. Aliyev BH (1999) Methodical instructions for use in drip irrigation impulsnogo technology. Baku, Azerbaijan.

2. Aliev BH, Aliyev ZH In Russian Azjerbajsanyn tjesjerrcfatlary mctjarjaggi cchcn Farmer tehnikasy irrigation. Baku, Azerbaijan.
3. Aliev ZH (2004) The Jesucci Irrigation Collection of the Erozia Aquaculture Irrigation and Institution of the Technology of the GubaKhachmaz Republic of Azerbaijan. Baku, Azerbaijan, pp. 179-183.

4. Aliyev BH, Aliyev ZH Computing AAE. pp. 43-51.

5. Agayev NA (2006) Farm and Land Acquisition of Water Resource. Erozija and Institute, pp. 28-32.

6. Aliyev ZH (2007) In Russian Irrigation of the administrative system without control of dams. Ecology and Water Tjasjarrcfaty scientific research and technology magazines. Baki, Azerbaijan.

7. AliyevZH (2002) In Russian Impulsive Drip irrigation systems and irrigation audit. Baku, Azerbaijan, pp. 107-109.

\section{(c) (i) \\ This work is licensed under Creative Commons Attribution 4.0 License}

To Submit Your Article Click Here:

Submit Article

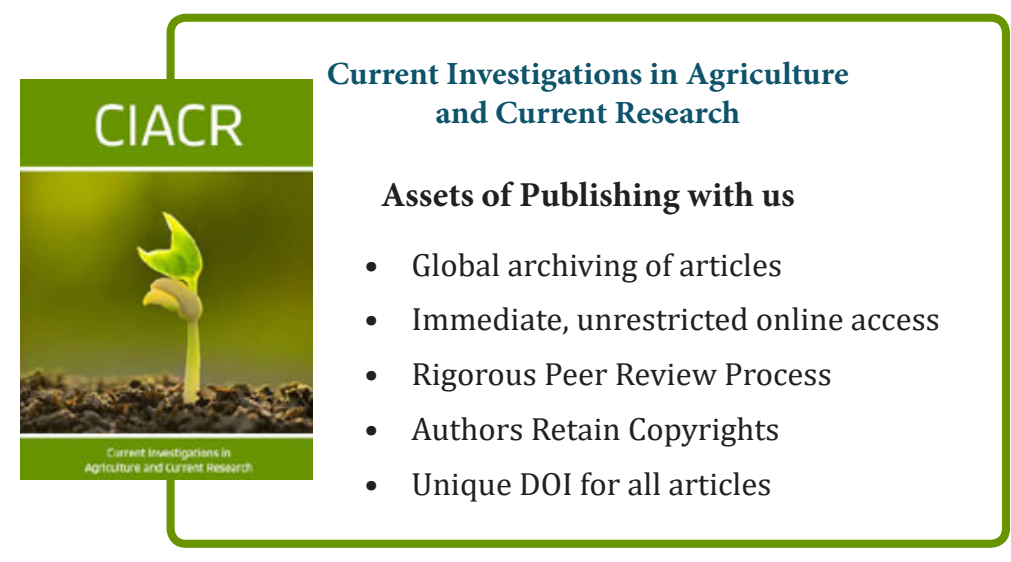

